\title{
A Multifunctional Horticulture Teaching Garden at Oregon State University
}

Ann M arie VanD erZ anden ${ }^{1}$ and Tom Cook ${ }^{2}$

AdDITIONAL INDEX WORDS. ornamental plants, landscape, experiential learning

Summary. O nce an abandoned property at the edge of campus, the 7,000 $\mathrm{ft}^{2}\left(650.3 \mathrm{~m}^{2}\right)$ horticulture teaching garden at $O$ regon State $U$ niversity has evolved from an overgrown residential lot into a well-defined and meticulously maintained garden. Since its beginning, an irrigation system, hardscapes, turf, bulbs, annuals, perennials, and woody plants have been installed by students enrolled in undergraduate horticulture courses. About 200 students use the garden annually as part of their formal instruction and it is currently integrated into the curricula of courses in landscape design, landscape construction and maintenance, and herbaceous and woody plant identification. Because the garden space is dynamic, curriculum changes can easily be accommodated.

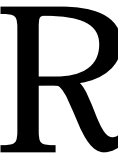

esearch into the learning process supports the concept of using teaching gardens to enhance student learning. The complex process of learning has been described by a number of experts and their theories continue to be redefined (Sfard, 1998). O ne broadly accepted theory of the learning process is a cyclical model in which students alternate between abstract conceptualization and concrete experience (Bawden, 1985; Kolb, 1984) ultimately enabling them to formalize relationships between theory and reality ( $M$ ichaels, 1990). H elping students see these relationships and connecting them in a tangible manner with the subject matter being taught is essential to their success.

$M$ any topics related to landscape horticulture lend themselves to the use of hands-on and experiential teaching methods. $M$ any of these teaching methods lead to increased interaction between students and faculty and can have a positive effect on student learning (Astin, 1993). Teaching gardens create opportunities for students to interact, apply theories discussed in classes, and gain practical hands-on experience. 
Theteaching garden is an integral part of five courses within the turf and landscape management option of the horticulture major at $O$ regon State U niversity. Formerly an abandoned residential lot at the edge of campus, the garden began to take shape in the mid-1980s, and was developed over the next 10 years into a teaching garden (Fig. 1). D uring that timeit wasused informallyin two undergraduate courses. Today, students use the garden in both formal and informal learning situations and have helped shape the development of the garden during the past 5

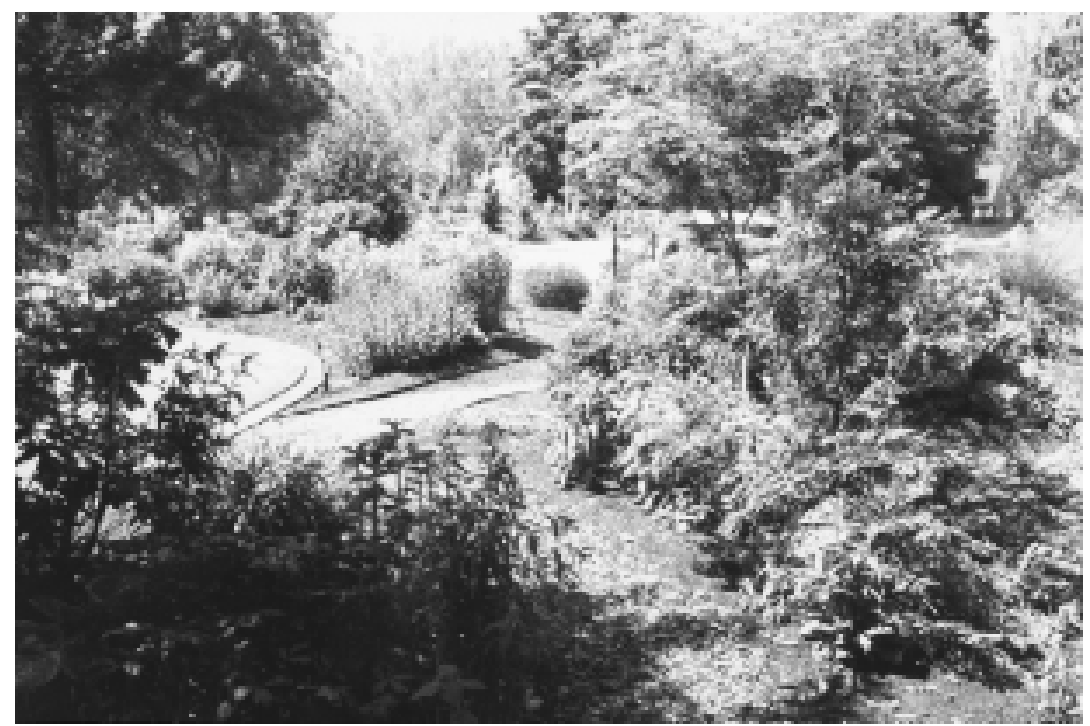

Fig. 1. H orticulture teaching garden located at $O$ regon State U niversity. T otal area is $7,000 \mathrm{ft}^{2}\left(650 \mathrm{~m}^{2}\right)$ and includes turf, perennial beds, a native plant collection, and hardscapes.

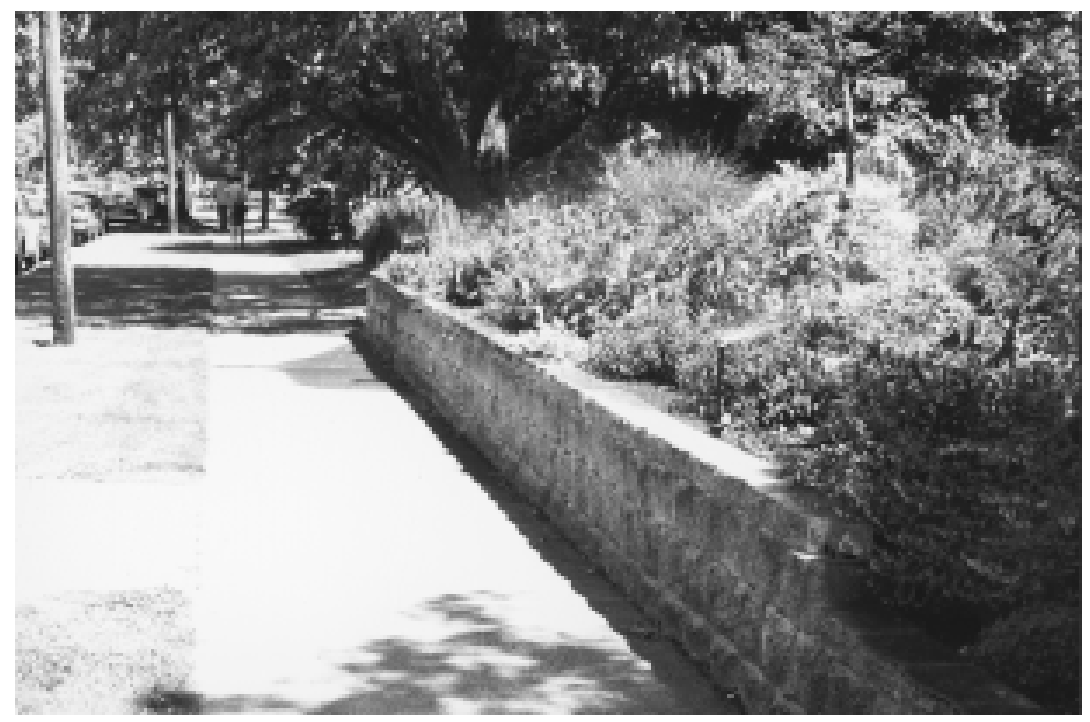

Fig. 2. Manufactured masonry wall project completed in 1998 by undergraduate students in the $L$ andscape $C$ onstruction class at $O$ regon State U niversity. years. A brief description of how the garden is used in each course follows.

\section{Landscape design}

Each fall, students in the Landscape D esign (H ORT 281) class are assigned areas within the garden to redesign. The goal isfor students to become familiar with the varying microclimates and different soil types in the garden as well as confront existing design problems. Students present their design proposals to the class for discussion and peer evaluation. After discussing the pros, cons and feasibility of actually completing the different projects, the class selects and recommends two proposals to be implemented by the Landscape Construction (HORT 358) class. I mplementing these designs over the past 3 years has resulted in limited areas within the garden that need improvement, and students are now developing designs for areas adjacent to the garden.

The response of these freshman and sophomore students to designing this tangible site has been positive. They enjoy the opportunity to create a professional landscape plan and to see it implemented by the $L$ and scape $C$ onstruction class. Students have commented that they feel a sense of ownership in the garden and, based on current learning theories, this connection to the garden should enhance the students' learning experience.

\section{Landscape construction}

Students in the L andscape Construction classes have helped transform the original garden space into interesting plant collections combined with brick paths, retaining walls and an irrigation system. While minor projects have been ongoing during the past 10 years, the major projects have taken place the past three spring terms.

In 1996, students created new planting beds and installed a collection of plants used in the plant identification courses, prepared and planted the turf area, and designed and installed an irrigation system. Projectsin 1997 included building 200 linear $\mathrm{ft}(61 \mathrm{~m})$ of a 3ft $(0.9-\mathrm{m})$ tall manufactured masonry wall, installing a gravel path along the west side of the garden, laying brick edging between the turf and planting beds, and installing additional perennial plant species. In 1998, students built a 50 linear-foot ( $15.2 \mathrm{~m})$ continuation of the manufactured masonry wall (Fig. 2 ), installed a sand-based brick path with a step and bark chip access paths throughout the planting beds.

These projects havegiven students experience with estimating (materials, time, and equipment) and installation, and their comments reflect positively on the skills devel- 
oped during these projects. An additional benefit is that students developed leadership, teamwork and collaborative problem solving skills. These interpersonal skills are equally important as their technical abilities and will be fundamental to their success as horticulture professionals.

\section{Landscape maintenance}

An initial assignment for students in L andscape M aintenance (HORT 315) is to develop a landscape maintenance plan for the garden. Because the garden is relatively small and the maintenancerequirements are easy to define, the assignment gives students an opportunity to develop maintenance estimating skills before moving on to larger, more complex projects. Students develop skills in measurement, production rates and times, and estimation. Students are then able to compare their estimates to the actual time spent maintaining the garden by student workers.

\section{Herbaceous and woody plant identification}

The collection of herbaceousand woody plant species in the garden changes regularly to reflect new and improved cultivars and to eliminate those that do poorly in the western 0 regon climate. The collection currently includes the majority of species covered in the $\mathrm{H}$ erbaceousPlant I dentification (H ORT 255) class and a number of species covered in the Woody Plant Identification (H ORT 226, 227 , and 228) classes. The garden also contains other species not specifically used in the classes, but which represent important companion plantings and highlight garden composition for sunny, shady and semi-shady locations. Because all plants are labeled with both scientific and common names, the garden provides a convenient and easily acces- sible living laboratory that students use in preparation for their identification exams.

The horticulture teaching garden at $O$ regon State U niversity has been a beneficial addition to undergraduate courses in the turf and landscape management option within the horticulture major. Through class activities, students are able to apply theories discussed during lecture sessions; develop landscape design and construction skills; gain a sense of the landscape maintenance time requirements; and broaden their knowledge of woody and herbaceous plant materials. Because the students use the garden for a number of classes and are significantly involved with how it develops, they have a sense of ownership in the garden. Their comments suggest they view the garden as not only a learning laboratory, but also a reflection of the skills they have developed during their undergraduate horticultural education.

\section{Literature cited}

Astin, A. 1993. What matters in college: Four critical years revisited. J ossey-B ass, San F rancisco, Calif.

Bawden, R.J . 1985. Problem-based learning-An Australian perspective, p. 43-57. In D. Bond (ed.). Proc. Workshop Problem-based Learning in the Education of Professionals. H igher Educ. Res. and D ev. Soc. of Australia, Sydney.

Kolb, D.A. 1984. Experiential learning: Experience as the source of learning and development. Prentice-H all, Englewood Cliffs, N .J.

M ichaels, T.E. 1990. Experiential learning using rapid-cycling Brassica campestrisL.J. Agron. E duc. 19(1):41-44

Sfard, A. 1998. O n two metaphors for learning and the dangers of choosing just one. Educ. Res. 27(2):4-13. 